\title{
Intracranial Basal Cell Carcinoma with Extensive Invasion of the Skull Base
}

\author{
Kafa Kaidesinin Belirgin İvazyonuyla Intrakraniyal Bazal Hücreli \\ Karsinom
}

\author{
Mehran MAHVASH \\ University Clinics of Schleswig Holstein, Campus Kiel, Department of Neurosurgery, Germany
}

Corresponding Author: Mehran MAHVASH / E-mail: mmahvash@yahoo.de

\begin{abstract}
Intracranial invasion of basal cell carcinoma is very rare. A case of a 71-year-old male patient is presented with extensive invasion of middle and posterior fossae, with nearly complete destruction of the petrous bone, involving cerebellopontine angle and cranial nerves by recurrent basal cell carcinoma of the auricular region on the right side. The clinical manifestation was cerebrospinal fluid otorrhoea, facial nerve palsy and trigeminal nerve impairment with hypoesthesia. The patient underwent surgery by combined retroauricular and temporal approach to the skull base. Adjuvant radiation of residual tumor and former tumor recurrence region was performed. MRI studies performed annually show no progress of the tumor. Our patient reports a good quality of life without new neurological deficits 6 years after surgery. Attention should be paid to the malignant nature of basal cell carcinoma making follow up care necessary. In indicated cases in which incomplete excision cannot be excepted and risk factors exist, follow up with CT or/and MRI should be performed to evaluate the infiltrative and invasive character of aggressive basal cell carcinoma and to rule out bone or cerebral infiltration.
\end{abstract}

KEYWORDS: Basal cell carcinoma, Intracranial invasion, Skull base

öz

Bazal hücreli karsinomun intrakraniyal invazyonu çok nadirdir. Orta ve posterior fossada belirgin invazyon, petröz kemiğin hemen hemen tümüyle harabiyeti, serebellopontin açı ve kraniyal sinirlerin sağ tarafta auriküler bölgede nüks bazal hücreli karsinom tarafından tutulduğu 71 yaşında bir erkek olguyu sunuyoruz. Klinik bulgular serebrospinal sıvı otoresi, fasiyal sinir palsisi ve hipoesteziyle birlikte trigeminal sinir tutulumu şeklindeydi. Hastada kafa kaidesine kombine retroauriküler ve temporal yaklaşımla cerrahi yapıldı. Kalan tümör ve daha önceki tümör nüks bölgesine adjuvan radyasyon uygulandı. Yılda bir yapılan MRG çalışmaları tümörde ilerleme göstermedi. Hastamız cerrahiden 6 yıl sonra yeni bir nörolojik defisit olmadan iyi bir yaşam kalitesi bildirmektedir. Bazal hücreli karsinomun malign özelliğine dikkat edilmelidir ve takip gereklidir. Tam olmayan eksizyonun kabul edilemeyeceği ve risk faktörlerinin bulunduğu, endike olan olgularda agresif bazal hücreli karsinomun infiltratif ve invaziv karakterini değerlendirmek ve kemik veya serebral infiltrasyonu ekarte etmek açısından BT ve/veya MRG ile takip yapılmalıdır.

ANAHTAR SÖZCÜKLER: Bazal hücreli karsinom, İntrakraniyal invazyon, Kafa kaidesi

\section{INTRODUCTION}

Basal cell carcinoma (BCC) is the most common malignant skin neoplasm with an increasing incidence worldwide (5). It is characterized by local infiltration and destruction of surrounding tissue. The mortality is low as metastasis or invasion of deeper structures are very rare $(1,5)$. Therefore $B C C$ has been also called a "semi-malignant" tumor. However, patients with $B C C$ have an increased risk of developing further $\mathrm{BCC}$ and also other malignant skin cancers $(1,5)$. This risk, the local destruction behavior and the possibility of aggressive invasion are signs of malignancy of BCC. BCC of the head and neck are the most common, $(1,3,5)$ particularly on the face and scalp due to the sun exposure and thus ultraviolet radiation, which is considered to be the main cause of developing BCC. Intracranial invasion is very rare and has been reported only in a few cases $(2,4)$. All these case reports describe intracranial infiltration of structures with supratentorial localization. Skull base infiltration located infratentorially and involving cranial nerves has not been described.

A case of a patient is presented with extensive invasion of middle and posterior fossae involving the cerebellopontine angle and cranial nerves. After review of the literature this is the first case presentation describing an intracranial infiltration of BCC with this localization and infiltration.

\section{CASE REPORT}

\section{History}

A 71-year-old male patient presented with a history of BCC of the right auricular region. The reason for admission was leaking of a clear fluid from the right ear and weakness of facial muscles on the right side. He was treated 3 years ago with excision of the auricular BCC with partial resection of the right ear. In addition plastic surgery was performed with 
reconstruction of the auricular region using skin-muscle transposition of latissimus dorsi. He had a known hearing loss on the right side.

\section{Examination}

In the current clinical and neurological examination, the patient presented the clinical manifestation of cerebrospinal fluid otorrhoea, facial nerve palsy and trigeminal nerve impairment with hypoesthesia on the right side. He had hyperreflexia of the right lower extremity and slight ataxia.

CT and MRI studies showed a massive recurrent of the tumor with an extensive infiltration of skull base involving the middle and posterior fossae, with nearly complete destruction of the petrous bone involving the carotid canal (Figure 1A-D). Infiltration involved facial and trigeminal nerves as well.

\section{Operation}

The patient underwent surgery by combined retroauricular and temporal approach to the skull base. After reopening of the skin and wide craniotomy the tumor could be removed completely in the region of middle and posterior fossae. The extent of intracranial infiltration of the tumor was $6 \times 8$ $\mathrm{cm}$. Subtotal resection of the tumor could be performed in the region closed to the carotid canal of petrous bone that was completely infiltrated and destructed. To avoid injuring of carotid artery and facial nerve residual tumor was left in the petrous area. Fascia lata and fat graft was used for reconstruction to avoid cerebrospinal fluid leak. Tumor removal was performed with reliable decompression and delineation of facial and trigeminal nerves. Histopathological results revealed a nodular BCC with bone infiltration.

\section{Postoperative Course}

Postoperatively the facial nerve palsy worsened temporarily. The patient had no other new neurological deficits. Adjuvant radiation of residual tumor and former tumor recurrence region was performed up to a total dose of $60 \mathrm{~Gy}$ (5x2 Gy peer Week). In the first follow up 3 months after surgery, the facial
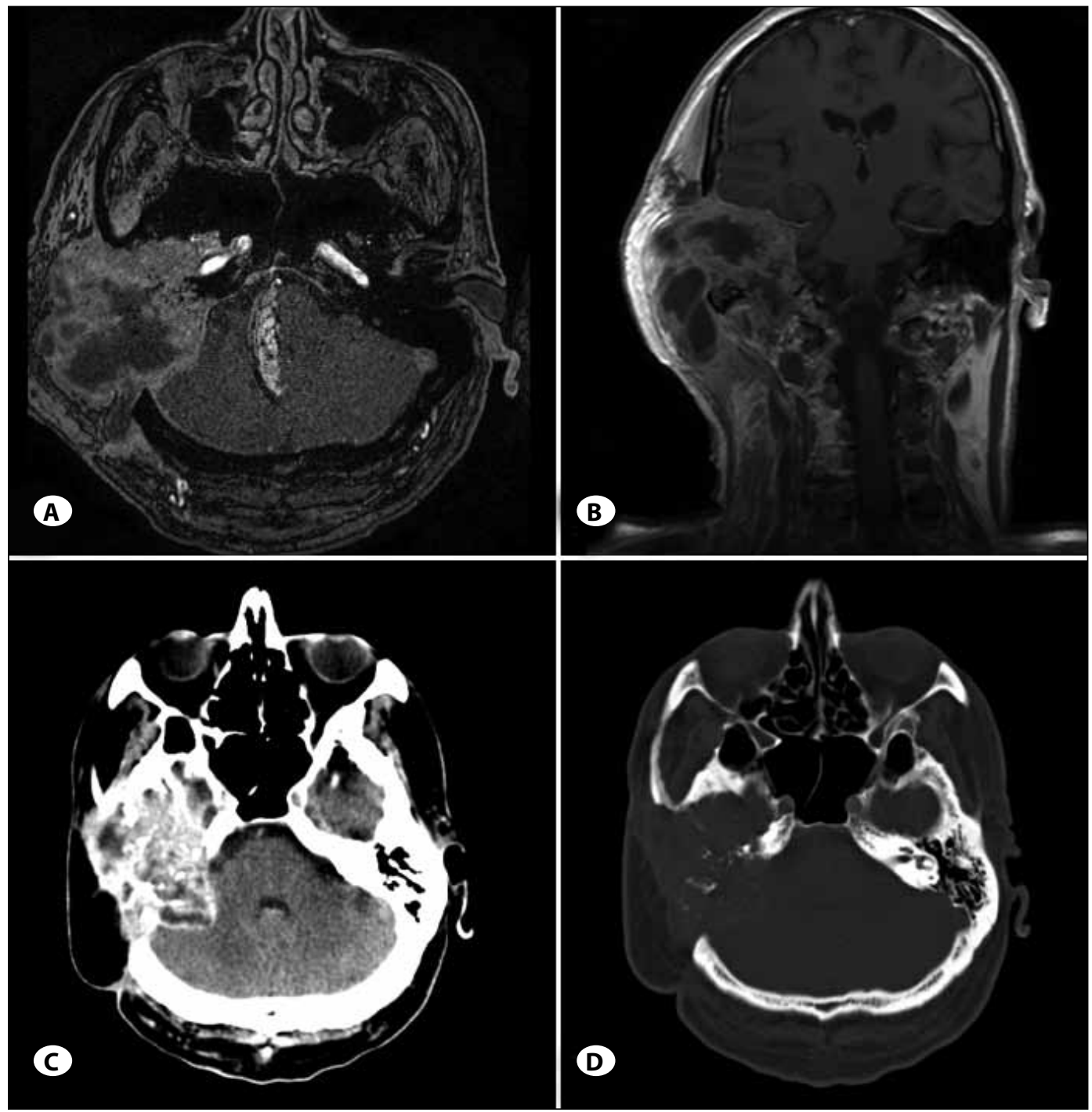

Figure 1: Preoperative axial (A) and coronal (B) T1 weighted MRI with contrast enhancement showing the extensive infiltration of the skull base by the basal cell carcinoma. Skin surface is not infiltrated. The tumor extended to the carotid canal and involved structures of the cerebellopontine angle.

C, D) Preoperative cranial CT: soft tissue window CT scan with contrast agent (C) and bone window CT (D) showing nearly complete destruction of the petrous bone. 
nerve was improved and had recovered to the preoperative status. The MRI studies performed annually showed no progress of the tumor. This was also confirmed in the last follow up in July 2011. Our patient reports a good quality of life without new neurological deficits 6 years after surgery.

\section{DISCUSSION}

We report an extremely rare case of extensive invasion of skull base by a recurrent basal cell carcinoma. In the literature few case reports are reported, particularly with invasion of supratentorial structures $(2,4)$. After review of the literature this is the first case report describing such an intracranial infiltration of BCC with this localization and extension. Due to the rarity, the treatment is a challenge. The treatment presented in this case report was successful with very good results. The patient reports 6 years after operation about a good quality of life and MRI studies show no tumor progression.

Aggressive BCC with infiltration of deeper tissue or metastasis are rare. In most cases the standard therapy is the complete local excision of the lesion, histopathological evaluation and regular dermatological follow up. In some cases radiotherapy and chemotherapy are indicated. The therapy is in the most cases curative with a good prognosis. Therefore, BCC has been considered as a semi-malignant skin tumor. However, these facts should not lead to the conclusion that BCC would not be malignant. BCC can have an aggressive infiltrative growth to the deeper structures and this can be inapparent for a long time. It is essential to be aware of the malignant nature of BCC and consider it as a malignant skin tumor with all consequences of necessity of follow up. The recurrence rate of BCC is high if the local excision is incomplete. Therefore the surgeons should take care to achieve complete primary excision. In addition the patients must be informed of the possibility of recurrent tumors and to attend the follow up care. Incomplete excision or neglect of BCC by the patients are factors that can influence the prognosis and make such extensive invasion of $\mathrm{BCC}$ possible.
$C T$ and MRI show the extent of the tumor very well. In most cases BCC occurs on the skin surface without sign of infiltration of deeper structures. Therefore in most cases performing of CT or MRI is considered by the physicians as not necessary. In cases of an aggressive BCC it means one reason for the extensive intracranial Infiltration of BCC. In indicated cases in which incomplete excision can not be excepted and risk factors are existing, follow up care with $\mathrm{CT}$ or/and MRI should be performed to evaluate the infiltrative and invasive character of an aggressive BCC and to rule out bone or cerebral infiltration.

Our patient was operated 3 years ago and it seems that possibly the excision was incomplete. The recurrent tumor was not apparent at the skin surface. In addition the massive swelling of the auricular and neck region (as shown on the MRI, Figure 1A-D) was neglected by the patient. The clinical manifestation of cerebrospinal otorrhoea, facial nerve palsy and trigeminal nerve impairment led to the admission of the patient to our department. These are late symptoms considering the extensive infiltration of the skull base and cerebellopontine angle. Follow-up care with CT or/and MRI would avoid neglecting the recurrent tumor, making an earlier verification possible with much easier treatment options.

\section{REFERENCES}

1. Diepgen $\mathrm{TL}$, Mahler V: The epidemiology of skin cancer. $\mathrm{Br} \mathrm{J}$ Dermatol 146(Suppl 61): 1-6, 2002

2. Kleydman Y, Manolidis S, Ratner D: Basal cell carcinoma with intracranial invasion. J Am Acad Dermatol 60(6):1045-1049, 2009

3. Lo JS, Snow SN, Reizner GT, Mohs FE, Larson PO, Hruza GJ: Metastatic basal cell carcinoma: Report of twelve cases with a review of the literature. J Am Acad Dermatol 24(5 Pt 1): 715-719, 1991

4. Schroeder M, Kestlmeier R, Schlegel J, Trappe AE: Extensive cerebral invasion of a basal cell carcinoma of the scalp. Eur J Surg Oncol 27(5): 510-511, 2001

5. Wong CS, Strange RC, Lear JT: Basal cell carcinoma. BMJ 327(7418): 794-798, 2003 